\section{Branimir Kalaš}

Nada Milenković ${ }^{2}$

University of Novi Sad, Faculty of Economics Subotica
SCIENTIFIC REVIEW ARTICLE

DOI:10.5937/ekonomika1702069K

Received: February, 22, 2017

Accepted: April, 03, 2017

\title{
THE ROLE OF VALUE ADDED TAX IN THE ECONOMY OF SERBIA
}

\begin{abstract}
Value added tax has been applied for six decades now and it doesn't represent a novelty in theory and practice. The aim of this paper is the effects of VAT on the economy and his relevance and position of total tax revenue. Authors emphasize significant share of this tax form in public finance of Serbia and the study is focused on a ten-year period 2005-2014. Using descriptive statistics and regression analysis, it's determined the strong and positive correlation between logarithms values of value-added tax and gross domestic product, value-added tax revenues, value-added tax and total revenues, but there is statistically no significant effect of observed variables.
\end{abstract}

Key words: VAT, GDP, total revenues, tax revenues, Serbia

JEL classification: C01, H2, H20

\section{УЛОГА ПОРЕЗА НА ДОДАТУ ВРЕДНОСТ У ЕКОНОМИЈИ СРБИЈЕ}

\begin{abstract}
Апстракт
Порез на додату вредност се примењује више од шест деценија и не представља новину у теорији и праксу. Циљ рада је приказати утицај ПДВ-а на економију и његову значајност и позицију у укупним пореским приходима. Аутори истичу значајно учешће овог пореског облика у јавним финансијама Србије, а рад је фокусиран на десетогодишњи период 2005-2014. године. Користећи дескриптивну статистику и корелацију, утврђена је јака и позитивна корелаџија између логаритмованих вредности пореза на додату вредност и бруто домаћег производа, пореза на додату вредност и пореских прихода и порезе на додату вредност и укупних прихода, али не постоји статистички значај утицај посматраних варијабли.
\end{abstract}

Кључне речи: ПДВ, БДП, укупни приходи, порески приходи, Србија

\footnotetext{
${ }^{1}$ branimir.kalas@ef.uns.ac.rs

${ }^{2}$ nadam@ef.uns.ac.rs
} 


\section{Introduction}

Tax is a compulsory payment created by the government of a country from which main products and services are performed. They are one of the main instruments of an economic policy (Karolak, 2011, p. 54). The effect of taxes on economic activity is one of the main fields of public finance. Tax system presents the totality of tax forms in the economy, respectively it's set of taxes that are linked by common goals which taxation should achieve. They are continuously changing in response to economic, political and administrative developments (Arsić, Altiparmakov, 2012, p. 2). States use taxes to covering public needs in order to ensure normal functioning of their institutions. Tosun and Abizadeh (2005) define taxes as one of the instruments of fiscal policy while Tabansi (2001) asserts that taxation is the system of imposing levy by the government against the income and profit or wealth of the individual, partnership, and corporations. German businessman Wilhelm Siemens is credited with coming up with the idea of VAT while the Maurice Laure has built into a system who was the joint director of the French tax authorities (Charlet, Owens, 2010, p. 943).

\section{Literature review}

There are many studies about VAT. Shenk and Oldman (2007) emphasize in their research that France was the first country who implemented VAT for the first time in the world by 1954 . Value Added Tax is a widely accepted indirect taxation system around the world and it has been implemented in more than 150 countries (Brown \& Gale, 2012). Many VAT system can be described as having a basic rate and special rates for some goods and services and also exemption status for certain economic activities and specific goods and services (Kamruddin, M 2012). Many researchers (Bird, 2005; Charlet and Buydens, 2012; Keen, 2013; Onwuchekwa, Aruwa., 2014) analyzed definition of VAT where it presents one of indirect tax that applied on consumption of goods and services and it's to be charged on the value of imports and on value added on goods and services supplied by one business to another while it reaches to final consumers. Ebrill et al (2001) noticed that VAT is a good way to raise resources and modernize the overall tax system while Jalata (2004) researched that indirect tax is a more significant instrument for the poorest economies to boost domestic revenues on goods and services. Grinberg (2009) calculated that VAT revenues are estimated to account for almost $20 \%$ of the total world's tax income. In the case of Romania, the studies on the VAT emphasize the importance of the conditions under which a VAT is fully optimal where an efficient tax structure requires the development of the VAT and income taxes (Pantazi and Straoanu, 2011, Keen, 2008, Zee, 2008). Bikas and Rashkauskas (2011) analyzed the effect of VAT standard tariff, reduced tariffs and shadow economy on income from this tax using multiple regression, correlation, and optimization and $\mathrm{C}$-effectiveness ratio analysis. Also, it included Lithuanian VAT structure, the dynamics of income from this tax and amendments in the Law on VAT where their results showed that amendments in the Law on VAT in terms of widening and narrowing the taxable base has influenced the amount of income from VAT. 
Bearing in mind that the paper highlights the effects of VAT on economic growth, authors are focused on many studies which were conducted on the contributions of VAT for the economic growth by using GDP as macro-level indicator (Unegbu and Irefin, 2011; Wawire 2011; Adereti, et al 2011; Hakim and Bujang 2011; Alemu 2011; Owolabi 2011, Worlu and Nkoro 2012; Stoilova and Patonov, 2012; Izedonmi and Okunbor, 2014; Chigbu, Ali, 2014, Kaczynska, 2015). Zimmermannova et al. (2016) analyzed the relationship between gross domestic product and unemployment and regional tax revenues such as value-added tax and income tax in the Czech Republic. They concluded a statistically significant positive relationship between observed variables.

\section{VAT implementation in Serbia}

Value Added Tax has been introduced in Serbia as of 1 January 2005 and has replaced sales tax. Serbia VAT law applies the destination principle to cross-border transactions where VAT registration threshold amounts to RSD 8 million.

Table 1. Type of Vat rates in Serbia

\begin{tabular}{||l|l||}
\hline \hline Vat rates & $20 \%$ \\
\hline \hline Standard rate & $\begin{array}{l}10 \% \text { applies to supplies of basic foodstuff, listed drugs, } \\
\text { daily newspapers, gas, hotel services, etc. }\end{array}$ \\
\hline \hline Reduced rate & $\begin{array}{l}\text { Export of goods; transportation and other services in } \\
\text { direct relation to export, transit or temporary import of } \\
\text { goods; entry goods in free zones and transportation and } \\
\text { other services in relation to the entry of goods into the } \\
\text { free zone, services performed on movables obtained by a } \\
\text { foreign user of the service in Serbia or imported for the } \\
\text { purpose of inward processing, repairing or incorporating } \\
\text { and then exporting, etc. }\end{array}$ \\
\hline
\end{tabular}

Source: Serbian Tax Card (2015) https://www.kpmg.com/RS/en/services/Tax/ Documents/KPMG_SerbianTaxCard_2015_WEB.PDF

The term exempt supplies include supplies of goods and services that are not subject to VAT: properties (except for the first-time transfer of ownership), financial and insurance services, rental of flats if used for housing, postal services, education and religious services, printing and sale of publications etc. In the following two figures, we can see movement of rates (standard) VAT in Serbia and it should be noted that the standard rate of VAT was moved 2012 year at $18 \%$ to $20 \%$ which is the actual rate in a current year. 
Figure 1. Standard VAT rate in Serbia from 2006 to 2015

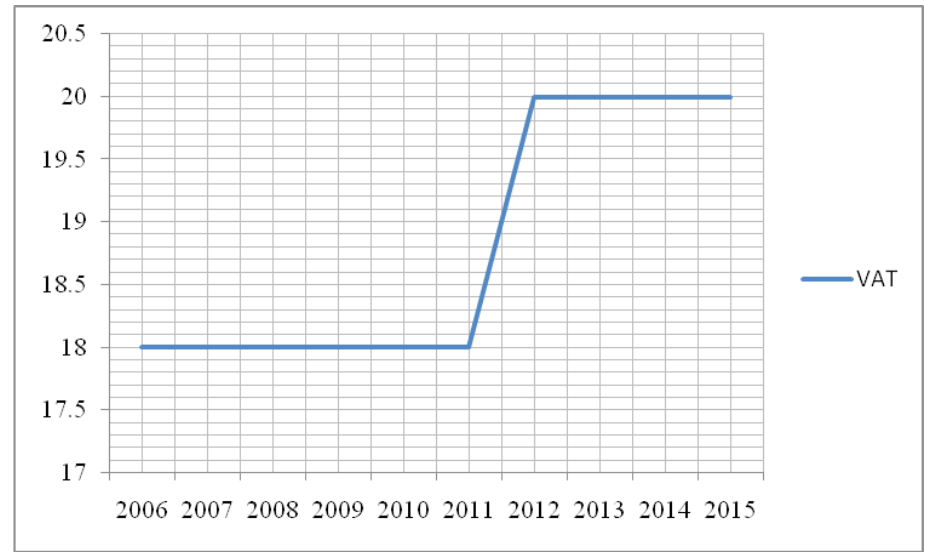

Source: Authors based on www.kpmg.com

Figure 1 shows a trend of standard VAT rate in Serbia in the period from 2006 to the 2015 year in Serbia. When this tax is introduced, the level of VAT was $18 \%$ whereby there were no changes to 2012 while the rate was increased by $2 \%$, respectively to $20 \%$.

Figure 2. Standard VAT rate in Serbia and EU, OECD, and World average

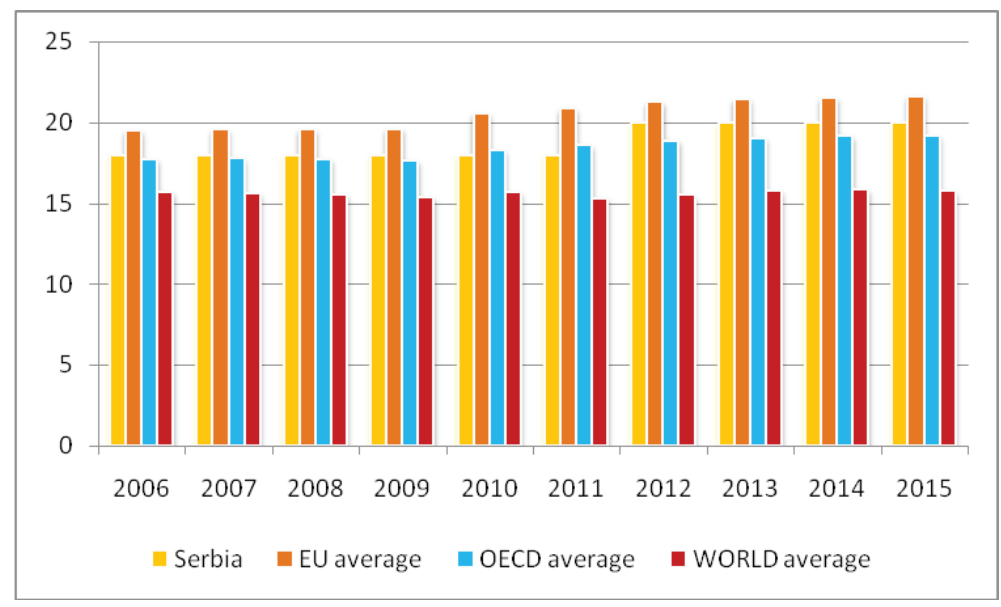

Source: Authors based on www.kpmg.com

Looking at the standard rate of VAT in Serbia, it's at the level of $20 \%$ which is $2 \%$ higher than the original rate after being introduced. In order to compare the height and level of this tax form in Serbia, it's included the average rate of VAT in the EU countries. In the period 2005-2010. the VAT rate was lower by $1.5 \%-2.5 \%$ of the average VAT rate in the EU. Although Serbia has been increased a rate of $18 \%$ to $20 \%$, it's still below the EU average. Also, it is higher than average rate in OECD countries and the world average rate which is moving at a level above $15.5 \%$. Specifically, in 2015, the average 
rate in OECD countries was $19.15 \%$ that is lower by $0.85 \%$ compared to the rate of VAT in Serbia while the average VAT rate in the world amounted to $15.78 \%$.

\section{Figure 3. Trend of revenues in Serbia (in mill RSD)}

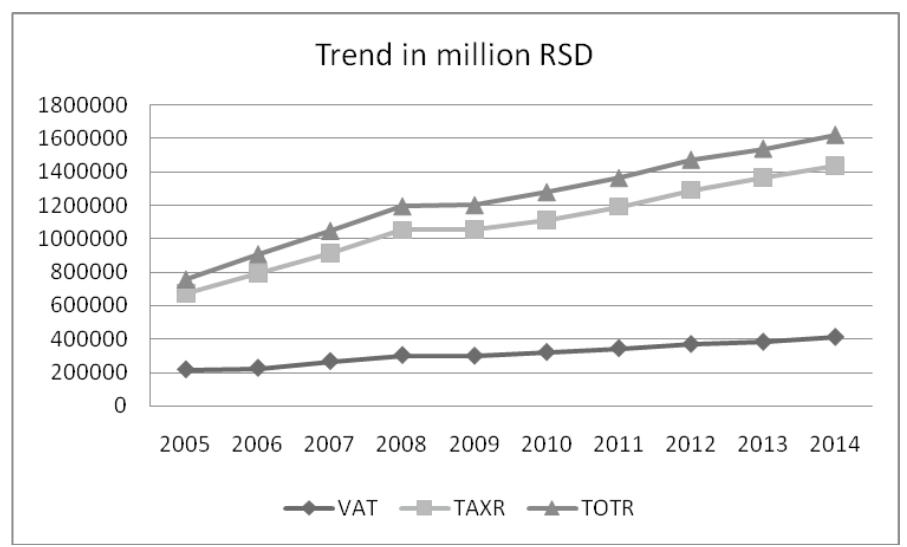

Source: Authors based on www.mfin.gov.rs

There is a growing trend of total revenues, tax revenues, and revenues based on VAT in the ten-year observed period. First, VAT revenues grew by an average of $7.5 \%$ while the highest growth was recorded in 2008 and 2008 when they had double rate growth of $17 \%$ and $13 \%$. On the other hand, the average growth of TAXR was $9.01 \%$ whereas the growth was very intense and exceeded $15 \%$ from 2007 to 2009 . TOTR have recorded similar trend where average growth is $8.09 \%$ in analyzed period.

Figure 4. VAT share in tax revenues and total revenues \%

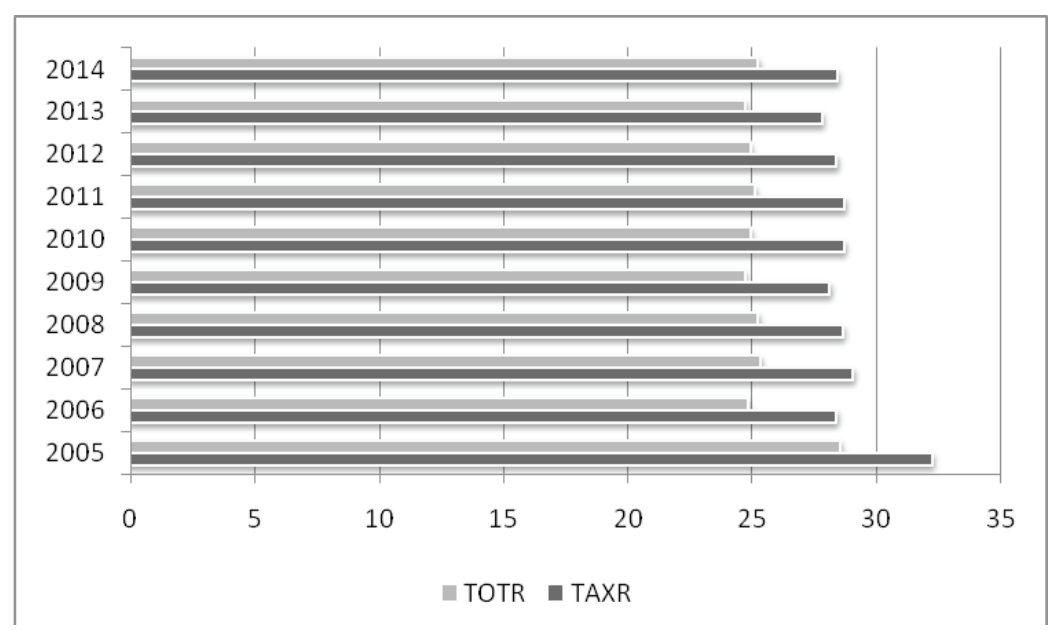

Source: Authors calculation 
Figure 4 reflects the share of VAT in TAXR and TOTR from 2005 to 2014. Looking this indicator, it's noticeable that value-added tax amounts almost a third of tax revenues and a quarter of total revenue. Precisely, at the beginning of the observed period, the highest share of VAT is noticed of 32.27 per cent of TAXR and 28.57 percent of TOTR which is greater for almost 4 percent compared to the end of 2014.

\section{Methodology and results}

This study aims to determine the impact of value added tax on the gross domestic product, tax revenues and total revenues of Serbia and find out the relationship between values of observed variables. Authors used annual data which were extracted from Ministry of finance reports from 2006 to 2015. In order to determine the contributions of Value Added Tax (VAT) to economic growth (GDP), Tax Revenue (TAXR) and Total Revenue (TOTR), we have determined models:

$\operatorname{LOGGDP}_{\mathrm{t}}=\mathrm{a}+\mathrm{b} \log \operatorname{Vat}_{\mathrm{t}}+\mathrm{e}_{\mathrm{t}}$

GDP is used as the dependent variable with VAT as the independent variable.

LOGTAXR $_{t}=\mathrm{a}+\mathrm{b} \log \mathrm{Vat}_{\mathrm{t}}+\mathrm{u}_{\mathrm{i}}$

Tax revenue is the dependent variable with VAT as independent variable.

LOGTOTR $_{\mathrm{t}}=\mathrm{a}+\mathrm{b} \operatorname{LogVAT}+\mathrm{i}_{\mathrm{i}}$

Total revenue is the dependent variable with VAT as independent variable.

Table 2. Descriptive statistics of observed variables

\begin{tabular}{|llllllll|}
\hline VARIABLE & MEAN & MEDIAN & $\begin{array}{l}\text { STANDARD } \\
\text { DEVIATION }\end{array}$ & MINIMUM & MAXIMUM & KURTOSIS & SKEWNESS \\
LOGGDP & 3.457659666 & 3.473053132 & 0.117699417 & 3.243286146 & 3.588607805 & -0.572905806 & -0.655810892 \\
LOGVAT & 5.486017392 & 5.491926117 & 0.093505414 & 5.334467825 & 5.612321776 & -0.80265054 & -0.445568174 \\
LOGTAXR & 6.025682648 & 6.034494583 & 0.10556695 & 5.825667542 & 6.158071961 & -0.136131287 & -0.697316201 \\
LOGTOTR & 6.08177 & 6.093071 & 0.104832 & 5.878514 & 6.209717 & -0.02457 & -0.78372 \\
\hline
\end{tabular}

Source: Authors calculation

Table 2 manifests analysis of logarithms value of GDP, VAT, TAXR and TOTR in the period from 2005 to the 2014 year in Serbia using descriptive statistics tools like a mean, median, standard deviation, minimum and maximum, Kurtosis and Skewness test. In this period, LOGGDP has an average value of 3.4576 with a standard deviation of 0.1177 where the minimum value of 3.2432 and the maximum value of 3.5886 .

Next, LOGVAT has recorded an average of 5.4860 with a standard deviation of 0.0933 while the minimum and maximum values are 5.3345 and 5.6123. Other indicators LOGTAXR and LOGTOTR have average values of 6.0255 and 6.0817 while the levels of minimum are 4.8256 and 5.8785 . The standard deviations of these two indicators are 0.1055 and 0.1048 while the maximum values are 6.1580 and 6.2097. If it looks at testing based on Kurtosis and Skewness, the coefficients of asymmetry are smaller than 0 and reflect a slight negative asymmetric distribution of logarithmic values of analyzed indicators and higher frequency of above average levels while negative values indicate that the curve is flattened. Next, it used correlation analysis to examine the relationship between variables VAT, GDP, TAXR, and TOTR. 
Figure 5. Correlation between VAT and GDP

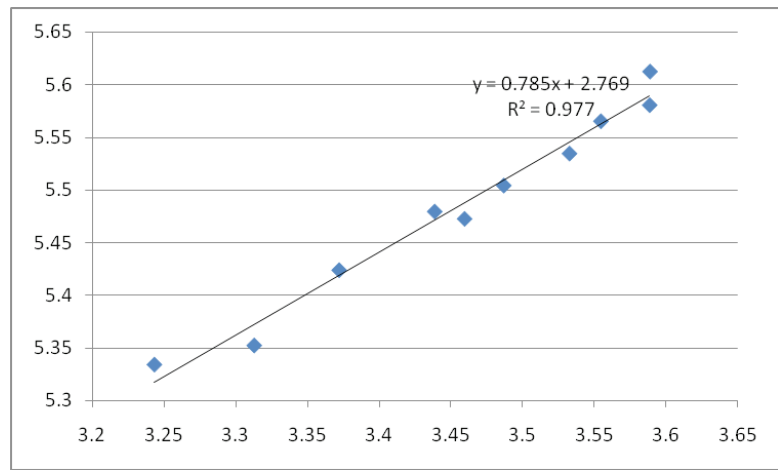

Source: Authors calculation

Based on Figure 5, the coefficient of determination of estimated relation between VAT and GDP in the period from 2005 to the 2014 year for the Serbia is 0.9888 which meaning that $99 \%$ of the variations is observed by the model, respectively of the variations logarithms of VAT. The correlation coefficient is 0.9778 which reflects a very strong and positive linear relation between the logarithms value of VAT and GDP. Based on the value of $p=0.05$ it manifested that value of VAT not significantly affects the value of GDP.

Figure 6. Correlation between VAT and TAXR and TOTR
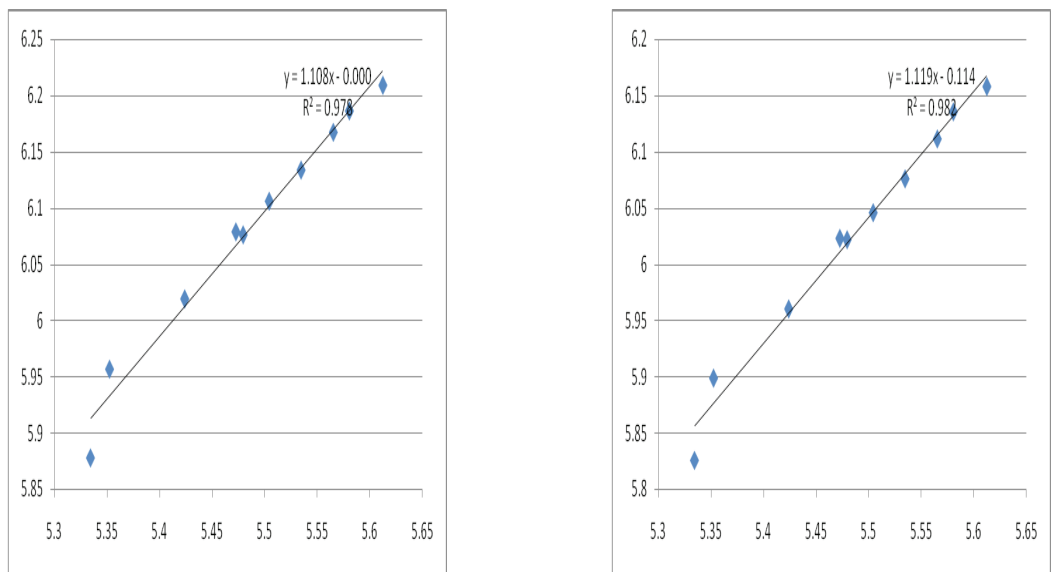

Source: Authors calculation

The next figure reflects two relationships in the same observed period in Serbia so what are included two additional variables as tax revenues (TAXR) and total revenues (TOTR) compared to value added tax (VAT). Both graphs show strong and positively correlation between observed variables where the value of the coefficient is at the level of $98 \%$ while the coefficient of determination is at the level of $99 \%$. On the other hand, this strong and positively correlation isn't significant based on the value of $p=0.05$ 


\section{Conclusion}

Every country looks for ways to increase their revenues and this facilitated many economies to introduce VAT on goods and services. Authors researched the effect of VAT on the economic growth of Serbia. Based on the study, VAT doesn't significantly impact on GDP, TAXR, and TOTR while the relationship between observed variables is strong and positively. First, the coefficient of correlation between VAT and GDP is 0.9778 which reflects their high and strong positive relationship. Further, if it includes variables TAXR and TOTR in relation to VAT, it can notice a simple correlation compared to the previous coefficient where the first correlation is 0.9827 while the second correlation is 0.9780 measured by the used coefficient. These results are significant and give a certain importance because almost $99 \%$ of the variations is explained by the model, respectively of the variations logarithms of VAT. The contribution of this paper is reflected in exploring a topic that isn't sufficiently researched in Serbia and there aren't many studies that analyzed this topic in Serbia. The future study can consider the same research topic with the analogous country as a comparative study and enhance the knowledge in the field.

\section{References}

Alemu, D. (2011), Empirical Analysis of The Contribution of Value added tax For Economic Development and Social Spending in Ethiopia (MSc Thesis). Addis Ababa University, Accounting and Finance. Addis Ababa: Addis Ababa University

Adereti, S.A., Sanni, M.R., Adesina, J.A. (2011), Value Added Tax and Economic Growth of Nigeria. European Journal of Humanities and Social Sciences Vol. 10, No. 1, pp. 456- 471.

Arsić, M., Altiparmakov, N. (2012), Equity Aspects of VAT in Serbia: Current System and Possible Reforms, Fiscal Council - Republic Serbia FC Research Paper 11/01

Bhatia, H. (2009), Public Finance-14th Edition). New Delhi: Vikas Publishing House PVT Ltd

Bikas, E., Rashkauskas., J. (2011), Value Added Tax Dimension: The Case of Lithuania. Ekonomika, Vol. 90, No. 1, pp. 22-38.

Bird, R.M. (2005), Value Added Taxes in Developing and Transitional Countries: Lessons and Questions. First Global International Tax Dialogue Conference on VAT. Rome: International Tax Dialogue

Brown, S., Gale, W. (2012), Tax Reform for Growth, Equity, and Revenue, UrbanBrookings Tax Policy Center, Washington, DC. USA.

Charlet, A., Owens, J. (2010), An International Perspective on VAT, Tax notes international, Tax Analysis, Vol. 59, No. 12, September 20, pp. 943-954.

Charlet, A., Buydens, S. (2012), The OECD International VAT/GST Guidelines: Past and Future Developments. World Journal of VAT/GST Law, Vol. 1, No. 2, pp. 175-184.

Chigbu, E.E., Ali, P.,I. (2014), Econometric Analysis of the Impact of Value Added Tax on Economic Growth in Nigeria, European Journal of Business and Management, Vol. 6, No. 18, pp. 31-36. 
Ebrill, L., Keen, M., Bodin, J-P., Summers, V. (2001), The Modern VAT. International Monetary Fund, Washington D.C.

Grinberg, I. (2009), Where Credit is Due: Advantages of the Credit-Invoice Method for a Partial Replacement VAT, Washington D.C.: American Tax Policy Institute Conference, pp. 309-358.

Hakim, T.A., Bujang, I. (2011), The Impact and Consequences of Tax Revenues' Components on Economic Indicators: Evidence from Panel Group Data. International Research Journal of Finance and Economics Vol. 63, pp. 83- 95.

Izedonmi, F.I.O., Okunbor, J.A. (2014), The Roles of Value Added Tax in the Economic Growth of Nigeria, British Journal of Economics, Management \& Trade, Vol. 4, No. 12, pp. 1999-2007.

Jalata, D.M. (2014), The Role of Value Added Tax on Economic Growth of Ethiopia, Science, Technology and Arts Research Journal, Jan-March 2014, Vol. 3, No. 1, pp. 156-161.

Kaczynska, A. (2015), The analysis of VAT revenue in Poland - the size and determinants, The 3rd Global Virtual Conference, April, 6-10, www.gvconference.com retrieved from: file://C:/Users/DELL/Downloads/The $\% 20$ analysis $\% 20$ of $\% 20$ VAT\%20reven $\% 20$.pdf

Kamrudin, M. (2012), Effect of Vat And Tax On Economy: An Analysis In The Context of Bangladesh, Research Journal of Finance and Accounting, Vol. 3, No. 7, pp. 64-70.

Karolak, A. (2011), Adaption Process of a Polish Tax Law to European Union Norms Harmonization of a Value Added Tax, Economics and Sociology, Vol. 4, No. 1, pp. 54-63.

Keen, M. (2008), VAT, Tariffs and Withholding: Border Taxes and Informality in Developing Countries, Journal of Public Economics, Vol. 92, No. 10-11, pp. 1892-1906.

Keen, M. (2013), The Anatomy of the VAT, International Monetary Fund, IMF Working Paper 13/111, Washington, D.C retrieved at: https://www.imf.org/external/pubs/ ft/wp/2013/wp13111.pdf

Onwuchekwa, J.C., Aruwa, S.A.S., (2014), Value Added Tax and Economic Growth in Nigeria, European Journal of Accounting Auditing and Finance Research, Vol. 2, No. 8, pp. 62-69.

Owolabi, S.A., A.T, T. O. (2011), Empirical Evaluation of Contribution of Value Added Tax to Development of Lagos State Economy. Middle Eastern Finance and Economics Vol. 9, pp. 24-34

Pantazi, F., Străoanu, B.M. (2011), Fiscal and Social-Economic Coordinates in the Analysis of the Salary Policy in Romania, Procedia - Social and Behavioral Science, Vol. 15, pp. 806-811.

Shenk, A., Oldman, O. (2007), Value Added Tax: A comparative Approach. New York: Cambridge University Press.

Stoilova, D., Patonov, N. (2012), An Empirical Evidence for the Impact of Taxation on Economy Growth in the European Union, Book of Proceedings - Tourism and Management Studies International Conference Algarve, Vol.3, ISBN 978-9898472-25-0 ESGHT- Portugal 
Tabansi, A.C.O. (2001), Nigerian Taxation for Students; Enugu, A.C. Ochiogu Publishers Limited.

Tosun, M.S., Abizadeh, S. (2005), Economic growth and tax components: An analysis of Tax changes in OECD. Appl. Econ., Vol. 37, pp. 2251-2263.

Unegbu, A.O. Irefin, A.D. (2011), Impact of VAT on economic development of emerging nations. Journal of Economics and International Finance Vol. 3, No. 8, pp. 492-503.

Wawire, N.H. (2011), Determinants of Value Added Tax Revenue in Kenya. CSAE (pp. 1-42). UK: St Catherine's College.

Worlu, C.N. Nkoro, E. (2012), Tax Revenue and Economic Development in Nigeria: A Macro-econometric Approach. Academic Journal of Interdisciplinary Studies Vol.1, No. 2, pp. 211-223.

Zee, H., (2008), Aspects of Interjurisdictional Sharing of the Value-Added Tax, Public Finance Review, Vol. 36, No. 2, pp. 147-168.

Zimmermannova, J., Skalickova, J., Siroky, J. (2016), What Can Tax Revenues Tell us about the Economic Activity of Regions? Economics and Sociology, Vol. 9, No. 1, pp. 114-128.

www.kpmg.com retrieved from: https:/home.kpmg.com/xx/en/home/services/tax/ tax-tools-and-resources/tax-rates-online/indirect-tax-rates-table.html

www.kpmg.com retrieved from: https:/www.kpmg.com/RS/en/services/Tax/ Documents/KPMG_SerbianTaxCard_2015_WEB.PDF

www.mfin.gov.rs. retrieved from: http://www.mfin.gov.rs/pages/issue.php?id=8528 